\title{
ANALISIS FAKTOR-FAKTOR YANG MEMPENGARUHI PENDAPATAN HOTEL (STUDI KASUS HOTEL BAHA-BAHA SEKONGKANG KABUPATEN SUMBAWA BARAT) TAHUN 2012-2016
}

\author{
Wahyu Haryadi', Binar Dwiyanto Pamungkas ${ }^{2}$, \\ ${ }^{1}$ Program Studi Manajemen/Fakultas Ekonomi dan Bisnis/Universitas Samawa, Indonesia \\ ${ }^{2}$ Program Studi Ekonomi Pembangunan/Fakultas Ekonomi dan Bisnis/Universitas Samawa, Indonesia \\ Email: ${ }^{1}$ wahyuharyadi@universitassamawa.ac.id \\ Email: ${ }^{2}$ binardwiyantopamungkas@universitassamawa.ac.id
}

\begin{abstract}
ABSTRAK
Tujuan penelitian ini untuk mengetahui seberapa jauh faktor-faktor yang diteliti yang mampu mempengaruhi pendapatan kamar, serta menentukan faktor yang paling dominan dalam mempengaruhi pendapatan kamar pada hotel Baha-Baha Sekongkang. Metode analisis data yang digunakan dalam analisis ini adalah koefesien regresi linier berganda. Variable-variabel yang diteliti yang dianggap berpengaruh terhadap pendapatan kamar pada Hotel Baha-Baha Sekongkang adalah tarifkamar, biaya promosi dan jumlah kamar. Berdasarakan metode penelitian, penelitian ini menggunakan metode interview dan ovservasi dalam memperoleh data, sedangkan data yang digunakan adalah data kualitatif dan kuantitatif. Berdasarkan analisis data yang dilakukan, ternyata faktor jumlah kamar merupakan faktor yang paling dominan dalam mempengaruhi pendapatan kamar. Faktor-faktor tariff kamar dan biaya promosi walaupun tidak sedominan faktor jumlah kamar, namun secara bersama-sama mampu mempengaruhi pendapatan kamar yang telah dibuktikan melalui uji $F$ dengan menggunkan program SPSS. Hasil dari penelitian ini adalah ternyata pada Hotel Baha-Baha Sekongkang jumlah kamar merupakan hal yang paling mendominasi pendapatan kamar yang ada
\end{abstract}

Kata kunci: biaya promosi, jumlah kamar dan pendapatan kamar, tarif kamar

\section{PENDAHULUAN}

Salah satu sektor usaha yang mempunyai kondisi persaingan sangat ketat saat ini adalah sektor industri perhotelan. Industri perhotelan saat ini adalah salah satu sektor penunjang kepariwisataan nasional. Hotel merupakan salah satu jenis akomodasi yang mempergunakan sebagai atau seluruh bangunan untuk menyediakan jasa pelayanan penginapan, makan dan minum, serta jasa lain yang digunakan untuk umum dan di kelola secara komersial serta memenuhi ketentuan persyaratan yang ditetapkan dalam surat keputusan (Surat Keputusan Menparpostel: KM 34 / HK 103 / MPT - 87). Dengan demikian dapat dikatakan bahwa hotel merupakan salah satu industri yang memiliki karakteristik khusus, tidak hanya menjual produk-produk berwujud seperti kamar, makanan, minuman, tetapi jugak menggunakan jasa dalam bentuk pelayanan dan keramah tamahan (Philip Kotler, 1997 : 83).

Menurut Basu Swasta (2001) faktor-faktor yang dapat mempengaruhi peningkatan pendapatan kamar adalah, tarif kamar, biaya promosi dan jumlah kamar. Promosi meliputi promosi penjualan, pemasaran langsung, periklanan dan penjualan personal. Program pemasaran tersebut digunakan perusahaan untuk menarik minat dan keinginan para konsumen terhadap produk yang ditawarkan oleh perusahaan. Dalam perusahaan jasa, promosi yang digunakan adalah promosi melalui internet, papan reklame, radio dan agen perjalanan.

Tarif merupakan salah satu faktor yang penting serta berpengaruh terhadap tingkat permintaan atas suatu produk. Dalam sebagian besar kasus, biasanya permintaan dan harga berbanding terbalik, yakni semakin tinggi harga, semakin rendah permintaan terhadap produk. Demikian sebaliknya, semakin rendah harga, semakin tinggi permintaan terhadap produk (Kotler, 1991); oleh karena itu, penetapan harga yang tepat perlu mendapat perhatian yang besar dari perusahaan. Jika harga yang ditetapkan oleh perusahaan tepat dan sesuai dengan daya beli konsumen, maka pemilihan suatu produk tertentu akan dijatuhkan pada produk tersebut (Basu Swastha dan Irawan, 2001). Dalam menetapkan strategi harga bisa dilakukan dengan potongan harga, premi pembayaran, kebijakan harga dan geografis. Hal ini 
akan berdampak pada tingkat penyewaan kamar di hotel. Faktor-faktor tersebut berinteraksi satu sama lain guna menciptakan suatu permintaan terhadap barang atau jasa yang ditawarkan sehingga dapat memberikan manfaat, diterima baik oleh konsumen yang pada ujungnya, pelanggan akan menjadi loyal dengan begitu pendapatan perusahaan akan terus meningkat.

Kabupaten Sumbawa Barat merupakan kabupaten yang berkembang dan wilayah yang cukup luas di provinsi Nusa Tenggara Barat. Kawasan Sumbawa Barat salah satu daerah yang kaya dengan tempat wisata. Kabupaten Sumbawa Barat salah satu di Indonesia yang memukau para wisatawan untuk bisa dapat berkunjungi. Pantai-pantai di Kabupaten Sumbawa Barat tidak kalah indah dengan pulaupulau sebelahnya, seperti Pulau Bali dan Lombok. Alam di Sumbawa Barat juga belum banyak dijamah, jadi masih sangat alami. Kabupaten Sumbawa Barat mempunyai wilayah yang banyak dikunjungi wisatawan baik dari dalam ataupun luar negeri dari berbagai Negara di dunia. Beberapa tempattempat perhotelan yang memiliki panorama indah menjadikan Kabupaten Sumbawa Barat mulai di kenal oleh wisatawan. Di kecamatan sekongkang Kabupaten Sumbawa Barat terdapat 6 hotel yaitu: (1) Hotel BahaBaha, (2) Hotel Sing Ken-Ken, (3) Hotel Tropical, (4) Hotel Yoyo's, (5) Hotel Villa Syurga, (6) Hotel Santai.

Salah satu hotel yang sering dikunjungi oleh wisatawan dari domestik maupun mancanegara di sekongkang adalah Hotel Baha-Baha Sekongkang yang terletak di Kabupaten Sumbawa Barat. Hotel ini berkapasitas 15 kamar dengan 3 kelas yang berbeda, yaitu Satndard Room, Deluxe Room dan Bungalow Room. Hotel Baha-Bahan difasilitasi dengan restoran, Cofe Shop, kolam renang, 24 hours Room Service dan lokasi Hotel Baha-Baha yang tepat di Birbir pantai yang memiliki pemandangan yang memukau dengan gulungan ombak yang tinggi dan pantai yang luas dengan pasir putih yang bersih sehingga para wisatawan banyak berkunjung di tempat hotel tersebut. Selain itu juga pesona pantai di Hotel Baha-Baha Sekongkang selalu memikat siapa saja yang datang, termasuk para peselancar dunia dimana tempat yang sering dikunjungi untuk berselancar di kabupaten Sumbawa Barat. Dengan kunjungan sejumlah wisatawan yang datang ke Hotel Baha-Baha Sekongkang menjadi keuntungan sendiri bagi hotel tersebut.
Selama periode tahun 2012-2016 jumlah kunjungan wisatawan dari domestik maupun mancanegara mengalami kenaikan terus menerus pada periode 2012-2015 dan mengalami penurunan pada tahun 2016. Penurunan jumlah kamar yang terjual di hotel ini tentunya harus diantisipasi oleh pihak hotel dengan melakukan penyelidikan mengenai penyebab jumlah tamu yang cenderung mengalami penurunan ini. Berdasarkan uraian diatas penulis tertarik untuk melakukan penelitian tentang faktor-faktor yang mempengaruhi pendapatan kamar usaha perhotelan. Maka penulis mengambil judul Analisis Faktor-Faktor Yang Mempengaruhi Pendapatan Hotel (Studi Kasus Hotel Baha-Baha Sekongkang Kabupaten Sumbawa Barat.

\section{Pengertian Pemasaran dan Konsep Pemasaran}

Pemasaran sebagai salah satu fungsi internal perusahaan, merupakan aktivitas sosial berupa pertukaran proudk antara produsen dan konsumen yang memberikan apa yang mereka butuhkan dan inginkan (Philip Kolter, 1993 : 3) Pemasaran tidak hanya sekedar pembelian dan penjualan saja, melainkan meliputi seluruh kegiatanperusahaan yang bertujuan menciptakan kepuasan pembelian melalu proses pertukara. Falsafah konsep pemasaran yang berorientasi paa konsumen bertujuan memberikan kepuasan pada konsumen tetapi setelah konsep pemasaran mengalami perkembangan pesat seiring semakin majunya tingkat kehidupan masyarakat, teknologi dan lingkungan, menyebabkan perusahaan tidak saja bertujuan memberi kepuasan pada konsumen tetapi juga memiliki kewajiban untuk memberi kemakmuran pada masyarakat dalam jangka panjang. Konsep pemasaran menyatakan bahwa kunci untuk meraih tujuan organisasi adalah menjadi lebih efektif daripada para pesaing dalam memadukan kegiatan pemasaran guna menetapkan dan memuaskan kebutuhan dan keinginan pasar sasaran. (Philip, 1997 :17).

\section{Promosi}

Promosi adalah arus informasi atau persuasi satu arah yang dibuat untuk mengarahkan seseorang atau organisasi kepada tindakan yang menciptakan pertukaran atau pemasaran (Basu Swastha, 1984 : 237). Promosi merupakan aspek penting dalam manajemen pemasaran, dan sering dikatakan sebagai 
"Proses Berlanjut". Ini disebabkan karena promosi dapat menimbulkan rangkaian kegiatan selanjutnya dari perusahaan.

Promosi mempunyai beberapa variabel yang dapat digunakan sebagai strategi untuk mencapai target penjualan. Pengkombinasian strategi yang terbaik dari beberapa variabel promosi dinamakan promotional mix. Ini dapat didefinisakan sebagai kombinasi strategi yang terbaik dari variabelvariabel periklanan, personal selling dan alat-alat promosi lain, yang semuanya direncanakan untuk mencapai program penjualan (Basu Swastha, 1990 : 349). Periklanan adalah kombinasi non individu, dengan sejumlah biaya melalui berbagai media yang dilakukan oleh perusahaan, lembaga non laba serta individu-individu (basu swastha, 1990 : 350). Pada prinsipnya periklanan bertujuan menyampaikan informasi untuk membujuk dan mengingat terhadap organisasi serta barang tawarannya dalam usaha meningkatkan reaksi pembeli potensial. Dari segi lain, tujuan periklanan yang rill adalah mengadakan komnikasi yang efektif, dimana yang menjadi sasaran adalah masyarakat atau pasar dan bukan seorang individu.

\section{Tarif / Harga}

Tarif / harga adalah uang yang dibutuhkan untuk mendapatkan sejumlah kombinasi dari produk dan pelayannya (Basu Swastha, 1990 : 241). Setiap perusahaan tentunya mempunyai tujuan tertentu dalam menentukan harga barang atau jasanya. Dapat kita temukan apa saja yang menjadi tujuan bagi perusahaan atau penjual dalam menetapkan tarif / harga produknya. Tujuan-tujuan tersebut antara lain :(a) Meningkatkan penjualan, (b) Mempertahankan dan memperbaiki market share, (c) Stabilisasi tariff/ harga, (d) Mencapai laba maksimal

Tingkat harga yang ditetapkan oleh perusahaan ternyata tidak terlepas dari faktor-faktor yang mempengaruhi tingkat tarif yang ditetapkan tersebut, yaitu: (a) Kondisi perekonomian yang tidak stabil tentu saja akan mempengaruhi tingkat harga. Pada masa resesi misalnya, tingkat tarif / harga berada pada suatu tingkatan yang lebih rendah, hal ini mengakibatkan terjadinya kenaikan harga-harga.

(b) Penawaran dan Permintaan, Sejumlah barang yang dibeli oleh pembeli pada tingkat tariff / harga tertentu berdasarkan hukum permintaan. Penawaran merupakan kebalikan dari permintaan, yaitu sejumlah barang yang ditawarkan oleh penjual pada suatu tariff / harga tertentu. Tariff / harga yang lebih tinggi mendorong jumlah yang ditawarkan lebih besar.

Elastisitas Permintaan Faktor lain yang mempengaruhi penentuan harga yaitu sifat permintaan pasar. Sifat permintaan pasar ini tidak hanya mempengaruhi volume yang dapat di jual. Untuk beberapa jenis barang, tarif/ harga volume berbanding terbalik jika harga naik maka penjualan akan naik. Dalam keadaan persaingan murni, penjualan yang berjumlah banyakaktif menghadapi pembeli yang banyak pula, sebab penjual dan pembeli yang banyak inilah yang akan mempersulit perorangan untuk menjual dengan harga yang lebih tinggi kepada pembeli lain. Harga barang yang ditetapkan dapat juga dipengaruhi oleh biaya yang dikeluarkan untuk membuat produk tersebut. Perusahaan akan menjual produknya dengan tarif / harga yang lebih tinggi dari biya yang dikeluarkan agar memperoleh keuntungan.

\section{Pendapatan Hotel}

Pendapatan diakibatkan oleh kegiatan-kegiatan perusahaan dalam memanfaatkan faktor-faktor yang dapat mempengaruhi pendapatan. Seluruh kegiatan perusahaan yang menimbulkan pendapatan secara keseluruhan menimbulkan dua akibat yaitu pengaruh positif atau pendapatan dan keuntungan dan pengaruh negatif atau beban dan kerugian. Selisih dari keduanya menjadi laba atau income dan rugi atau less. Menurut tim penyusun Ikatan Akuntansi Indonesia dalam bukunya Standar Akuntansi Keuangan melalui PSAK No. 23, menjelaskan pendapatan adalah arus masuk bruto dari manfaat ekonomi yang timbul dari aktivitas normal perusahaan selama suatu periode bila arus masuk itu mengakibatkan kenaikan ekuitas, yang tidak berasal dari kontribusi penanaman modal. Pendapatan Yang Ada Di Hotel Pendapatan Kamar. Menurut Sugiarto (1997:55) yang dimaksud pendapatan kamar adalah jumlah total yang diperoleh dari penjualan kamar dan jasa lainnya dalam satu malam, dengan jenis cara pembayaran yang bermacam-macam. Pendapatan kamar merupakan sumber pendapatan terbesar yang dihasilkan hotel, disamping pendapatan dari hasil penjualan fasilitas lainnya, seperti penjualan makan dan minuman, serta pelayanan yang diberikan selama menginap di Hotel. Hasil dari total pendapatan. 


\section{Jumlah Kamar Berdasarkan Jenis Hotel}

Pengklasifikasian hotel berbintang di Indonesia dibagi menjadi 5 tingkatan. Peninjauan terhadap klasifikasi dilakukan 3 tahun sekali dengan mempertimbangkan berbagai aspek. Berdasarkan SK Menparpostel RI No. PM/PW 301/PHB-77 klasifikasi jenis hotel berdasarkan bintang sebagai berikut: (a) Hotel berbintang 1, (b) Hotel berbintang 2, (c) Hotel berbintang 3, (d) Hotel berbintang 4, (e) Hotel berbintang 5. Adapun persyaratan yang harus dipenuhi hotel berbintang yaitu: Dikatakan hotel berbintang satu apabila sekurang-kurangnya memiliki 15 kamar, satu kamar suite room, memiliki restoran dan bar.

Dikatakan hotel berbintang dua apabila sekurang-kurangnya memiliki 20 kamar, dua suite room, memiliki restoran dan bar. Dikatakan hotel berbintang tiga apabila sekurang-kurangnya memiliki 30 kamar, tiga suite room, memiliki restoran dan bar. Dikatakan hotel berbintang empat apabila sekurang-kurangnya memiliki 50 kamar, empat suite room, memiliki restoran dan bar. Dikatakan hotel berbintang lima apabila sekurangkurangnya memiliki 100 kamar, lima suite room, memiliki restoran dan bar.

\section{METODE PENELITIAN}

\section{Jenis Penelitian}

Penelitian ini menggunakan jenis penelitian asosiatif. Menurut Sugiyono (2012:11), "penelitian asosiatif merupakan penelitian yang bertujuan untuk mengetahui pengaruh antara dua variabel atau lebih". Penggunaan jenis penelitian ini sesuai dengan maksud dan tujuan penelitian yaitu untuk mengetahui bagaimana faktor tarif kamar, biaya promosi dan jumlah kamar yang mempengaruhi pendapatan Hotel Baha-Baha Sekongkang Kabupaten Sumbawa Barat.

\section{Jenis Data Dan Sumber Data}

Data Kuantitatif Merupakan data yang diperoleh dari responden dalam bentuk angkaangka (Sugiyono, 2014:15). Dalam penelitian ini data kuantitatif di peroleh dari Hotel Baha - Baha Sekongkang yang berupa jumlah pengunjung, tarif kamar yang ditetapkan, biaya promosi dan pendapatan kamar hotel. Data Kualitatif Merupakan dayta yang berbentuk kata-kata bukan dalam bentuk angka-angka (Sugiono, 2014:15). Dalam penelitian ini data kualitatif diperoleh dari dokumen berupa catatan tentang profil Hotel Baha - Baha Sekongkang Kabupaten Sumbawa Barat. Sedangkan menurut Indrianto dan Supomo (1999) berdasarkan sumbernya, sumber data umumnya ada 2 (dua) yaitu, sumber data primer dan data sekunder. Dalam penelitian ini menggunkan data sekunder yang di peroleh melalui hotel tersebut, untuk memperoleh informasi dari referensi, dan sumber lainnya yang berhubungan dengan penelitian. Data sekunder ini mengacu pada objek penelitian yakni Hotel Bah-Baha Sekongkang.

\section{Teknik Analisis Data}

Sugiyono (2012 : 244) menjelaskan bahwa analisis data adalah proses untuk mencari dan menyusun secara sistematis data yang diperoleh dari hasil pengumpulan data (wawancara, catatan lapangan, dan dokumentasi) dengan cara mengorganisir data ke dalam kategori, menjabarkan ke dalam unit-unit, melakukan sintesa, menyusun kedalam pola, memilih mana yang penting dan yang akan di pelajari, dan membuat kesimpulan sehingga mudah dipahami oleh diri sendiri dan orang lain. Dalam penelitian ini menggunakan analisis regresi linear berganda yaitu, hubungan secara linear antara beberapa variabel independen $(\mathrm{X})$ dengan variabel dependen $(\mathrm{Y})$, atau dalam artian ada variabel yang mempengaruhi dan ada variabel yang dipengaruhi. Model regresi linier berganda dalam penelitian ini yaitu :

$$
\mathrm{Y}=\mathbf{a}+\mathbf{b} 1 \mathrm{X} 1+\mathrm{b} 2 \mathrm{X} 2+\mathrm{b} 3 \mathbf{X} 3+\mathrm{e}
$$

$$
\begin{aligned}
& \text { Keterangan: } \\
& \begin{aligned}
\mathrm{Y}= & \text { Variabel dependen (nilai yang } \\
& \text { diprediksikan) } \\
\mathrm{X} 1, \mathrm{X} 2, \mathrm{X} 3 \mathrm{=} & \text { Variabel independen } \\
\mathrm{a} & \text { Konstanta } \\
\mathrm{b} 1, \mathrm{~b} 2, \mathrm{~b} 3= & \text { Koefisien regresi } \\
\mathrm{e} & \text { error }
\end{aligned}
\end{aligned}
$$

\section{HASIL DAN PEMBAHASAN}

Berdasarkan pada hasil analisis yang telah dilakukan, maka persamaan regresi yang terbentuk adalah sebagai berikut: 


$$
Y=193,176 \times 1+0,510 \times 2+445,208 \times 3+e
$$

Keterangan:

$\mathrm{Y}=$ Pendapatan Kamar

$\mathrm{X} 1=$ Tarif Kamar

$\mathrm{X} 2$ = Biaya Promosi

$\mathrm{X} 3$ = Jumlah Kamar

$\mathrm{e}=$ error

Dari persamaan di atas, dapat dijelaskan sebagai berikut Koefisien regresi pada variabel tarif kamar (X1) sebesar 193,176 adalah positif. Artinya bila terjadi peningkatan Rp1 variabel tarif kamar dimana faktor-faktor lain konstan akan dapat meningkatkan pendapatan kamar sebesar Rp193,176. Koefisien regresi pada biaya promosi (X2) sebesar 0,510 adalah positif. Artinya bila terjadi peningkatan Rp1 variabel biaya promosi dimana faktor-faktor lain konstan dapat meningkatkan pendapatan kamar sebesar Rp0,510. Koefisien regresi pada jumlah kamar (X3) sebesar 445,208 adalah positif. Artinya bila terjadi peningkatan 1 satuan variabel jumlah kmar dimana faktor-faktor lain konstan akan dapat meningkatkan pendapatan kamar Rp445,208.

Pada bagian ini akan dipaparkan pembahasan mengenai hasil analisis yang telah dilakukan. Dapat diketahui bahwa seluruh variabel independen signifikan terhadap variabel dependen. Penjelasannya adalah sebagai berikut: Hipotesis pertama yang diajukan dalam skrpsi ini adalah faktor tarif kamar, biaya promosi dan jumlah kamar secara bersama sama mempengaruhi penjualan kamar. Untuk itu dilakukan pengujian $\mathrm{F}$ test, dan dari hasil perhitungan diketahui bahwa $\mathrm{F}$ hitung 103,408 dengan tingkat kesalahan 0 , karena $F$ hitung 103,408 lebih besar dari F tabel 2,85 maka hipotesis pertama terbukti.

Berdasarkan perhitungan regresi dengan menggunkan SPSS diperoleh koefesien regresi untuk variabel tarif kamar adalah sebesar 193,176. Hal ini berarti variabel tarif kamar menyumbang kenaikan pendapatan kamar sebesar Rp193,176 setiap penambahan tarif kamar. Pengaruh variabel tarif kamar terhadap pendapatan kamar secara individu ditunjukan pada hasi uji t, Sebesar t hitung 4,326 lebih besar dari t tabel 2,120, ini berarti variabel tarif kamar berpengaruh signifikan terhadap pendapatan kamar. Variabel selanjutnya adalah diperoleh koefesien regresi untuk variabel biaya promosi adalah sebesar 0,510 . Hal ini berarti variabel biaya promosi menyumbang kenaikan pendapatan kamar sebesar Rp. 0,510 setiap penambahan biaya promosi. Pengaruh variabel biaya promosi terhadap pendapatan kamar secara individu ditunjukan pada hasi uji $t$, Sebesar $t$ hitung 0,262 lebih besar dari t tabel 2,120, ini berarti variabel biaya promosi tidak berpengaruh signifikan terhadap pendapatan kamar. Variabel jumlah kamar diperoleh koefesien regresi untuk variabel jumlah kamar adalah sebesar 445,208. Hal ini berarti variabel jumlah kamar menyumbang kenaikan pendapatan kamar sebesar Rp. 445,208 setiap penambahan jumlah kamar. Pengaruh variabel jumlah kamar terhadap pendapatan kamar secara individu ditunjukan pada hasi uji t, Sebesar t hitung 9,940 lebih besar dari t tabel 2,120, ini berarti variabel jumlah kamar tidak berpengaruh signifikan terhadap pendapatan kamar.

\section{KESIMPULAN}

Berdasarkan hasil penelitian yang didapatkan maka dapat diperoleh keseimpulan sebagai berikut:

1. Tarif kamar berpengaruh signifikan terhadap pendapatan kamar Hotel Baha-Baha Sekongkang.

2. Biaya promosi tidak berpengaruh signifikan terhadap pendapatan kamar Hotel Baha-Baha Sekongkang.

3. Jumlah kamar berpengaruh signifikan terhadap pendapatan kamar Hotel Baha-Baha Sekongkang.

4. Tarif kamar, biaya promosi dan jumlah kamar secara bersama-sama berpengaruh signifikan terhadap pendapatan kamar Hotel Baha-Baha Sekongkang.

\section{REKOMENDASI}

1. Berdasarkan hasil analisis yang dilakukan ternyata varibael yang paling berpengaruh terhadap pendapatan kamar adalah varibel jumlah kamar. Dengan kondisi yang demikian sebaiknya perusahaan hotel dapat menambah jumlah kamar yang tersedia untuk dapat meningkatkan pendapatan kamar.

2. Bagi varibael tarif kamar dan biaya promosi yang masuk sebagai faktor-faktor yang dianggap mempengaruhi pendapatan kamar, sebaiknya perusahaan tetap memberikan prioritas yang cukup walau tidak sebesar yang diberikan pada variabel jumlah kamar. Dikarenakan walaupun secara tidak langsung mampu mempengaruhi penjualan kamar 
Wahyu Haryadi, Binar Dwiyanto Pamungkas - Analisis Faktor-Faktor Yang Mempengaruhi Pendapatan Hotel (Studi Kasus Hotel Baha-Baha Sekongkang Kabupaten Sumbawa Barat) Tahun 2012-2016

namun apabila dilakukan secara bersama-sama variabel-variabel terebut mampu memberikan kontribusi yang cukup besar bagi pendapatan kamar pada Hotel Baha-Baha Sekongkang.

\section{DAFTAR PUSTAKA}

Alma, B. (2004). Manajemen Pemasaran dan Pemasaran Jasa. Bandung: Alfabeta.

Assauri, Sofjan.(2007). Manajemen Pemasaran, Jakarta: PT. Raja Grafindo Persada.

Charles W. Lamb, Joseph F. Hair, CarlMcdaniel. (2001). Pemasaran Edisi Pertama. Jakarta: Salemba Empat.

Gitosudarmo, Indriyo. (1994). Manajemen Pemasaran, Yogyakarta: BPFE.

Henry Simamora. (2002). Akuntansi Manajemen, Jakarta: Salemb Empat.

Hurriyati, R. (2005). Bauran Pemasaran dan Loyalitas Konsumen. Bandung: Alfabeta.

Husein Umar. (2002). Riset Pemasaran dan Perilaku Konsumen, Cetakan kedua. Gramedia, Jakarta: Pustaka Utama.

Ikatan Akuntan Indonesia.(2002). Standar Akuntansi Keuangan, Jakarta: Salemba Empat.

Khotijah, S. (2004). Smart Strategy of Marketing. Bandung: Alfabeta.

Kotler, Philip and Gary Armstrong. 1991. Principle of Marketing, Fifth edition New Jersey: PrenticeHall Inc.

(1997). Manajemen Pemasaran: Analisis, Perencanaan, Implementasi, dan Kontrol, Jakarta: Prenhalindo.

(2008). Manajemen Pemasaran, Edisi Milenium diterjemahkan Benyamin Molan, Jakarta: PT. Prenhallindo.
Kusnadi. (2000). Akuntansi Keuangan Menengah (Intermediate) (Prinsip, Prosedur, dan Metode), Malang: Universitas Brawijaya.

Machfoedz, Mahmud. (2010). Komunikasi Pemasaran Modern, Cetakan Pertama. Yogyakarta: Cakra Ilmu.

Nastalia, Hetty. (2013). Pengaruh Biaya Promos terhadap Penjualan pada PT. Mahakam Vision Network di Samarinda, Samarinda: e-JournaI ilmu Administrasi Bisnis.

Rangkuti, Freddy. (2009). Strategi Promosi yang Kreatif dan Analisis Kasus Integrated Marketing Communication, Jakarta: PT. Gramedia Pustaka Utama.

Rumekso. (2001). Housekeeping Hotel. Yogyakarta: Andi.

Sugiyono. (2001). Metode Penelitian Administrasi. Bandung: Alfabeta.

Sulastiyono, A. (2006). Manajemen Penyelenggaraan Hotel. Bandung: Alfabeta.

Swastha, Basu DH dan irawan, (1990). Manajemen Pemasaran Modern. Edisi kedua, Yogyakarta: Liberty.

(2001). Manajemen Pemasaran Modern, Yogyakarta: BPFE. Theodorus M. Tuanakotta. (2000). Teori Akuntansi, Jakarta: Fakultas Ekonomi Universitas Indonesia.

Swastha, B. (1999). Azas-Azas Marketing. Edisi Ketiga. Yogyakarta: Liberty.

Tjiptono, Fandy. (1997). "Prinsip - prinsip Total Quality Service”. Yogyakarta: CV. AndiOffset.

Walpole, R. E. (1995). Pengantar Statistika. Edisi Ketiga. Jakarta: Gramedia Pustaka Utama. 